\title{
Basis of Disease Manifestation: A Molecular and Ayurvedic Approach with an Integrated Concept of Ayurgenomics
}

\author{
Shriti Singh ${ }^{1 *}$, Sangeeta Gehlot ${ }^{1}$ and N. K. Agrawal ${ }^{2}$ \\ 'Department of Kriya Sharir, Faculty of Ayurveda, Institute of Medical Sciences, Banaras Hindu University, \\ Varanasi-221005, Uttar Pradesh, India; singhshriti@gmail.com, sangeetagehlot@gmail.com \\ 2Department of Endocrinology and Metabolism, Institute of Medical Sciences, Banaras Hindu University, \\ Varanasi-221005, Uttar Pradesh, India; drnkavns@gmail.com
}

\begin{abstract}
Ayurveda and contemporary science comprehends human body as model to understand disease state from very different perspective hence their methodology to describe disease manifestation also seems very different as they observe same problem from different viewpoints. For more precision in healthcare system it is essential that best of both systems need to be integrated, In Ayurvedic texts, the description of concept of basic constitution/Prakriti in health and disease states is well described. The scripts are not clearly understandable and hence its importance has not been properly understood by contemporary biological researchers and thus not utilized. According to Ayurveda individual's basic constitution (Prakriti) influences and directs one's disease status, its treatment \& lifestyle regimen. In genomics, individual's basic constitution is decided by its genetic makeup. The current trend in Ayurveda-related biomolecular studies is establishment of high correlation between Prakriti and Genomics. This approach of Ayurgenomics would facilitate the development of alternative methods for cost effective screening of predisposed individuals in the population. This would result in development of an integrated approach to systems biology for disease and health state. For the establishment and success of this concept the prerequisite is integration of Ayurveda into mainstream contemporary biology to achieve global acceptability for the concepts and science of Ayurveda, and for this Ayurvedic concept based phenotypic (Prakriti) assessment needs to be made so that difference among individuals from large population based on their physical, physiological and psychological status can be observed and they can be categorized by their specific predominant Prakriti i.e. Vata, Pitta, Kapha. Information about individual predominant Prakriti can be further analyzed on certain genomic parameters related to gene expression, genetic, epigenetic and biochemical factors, which can be further utilized for Integration of Ayurveda with Genomics for systems biology approach in predictive and personalized medicine.
\end{abstract}

Keywords: Ayurgenomic, Genome, Prakriti, System Biology

\section{Introduction}

Ayurveda is an age-old Indian healing system with personalized approach documented and practiced since ages. Ayurveda has a unique way of classifying human population based on individual constitution or Prakriti. Tridosha theory of Ayurveda recognizes principles of movement (Vata), metabolism (Pitta), and strength (Kapha) as distinct phenotypic groupings. As per this system, every individual is born with his or her own basic constitution, which upto a great extent regulates inter-individual variability in susceptibility to diseases and response to external environment, diet and drugs. In the province of modern predictive medicine, efforts

*Author for correspondence 
are being directed towards capturing disease phenotypes with greater precision for successful identification of markers for prospective disease conditions. It is an emerging approach for disease treatment and prevention that takes into account individual variability in genes, environment, and lifestyle for each person. It seems to be the continuation or progression of personalized predictive medicine.

\section{Materials and Methods}

Information extracted from various classics i.e. Charaka, Sushruta, Ashtanga Hridaya and Ashtanga Sangraha and published information on recent research developments on Prakriti including original articles in Pubmed, Scopemed, Pubmed Central Databades, Dhara online database and other allied databases were taken into consideration for the review. Reported data were analyzed and embodied for the current review.

\section{Concept of Disease Manifestation}

There are various views regarding the disease manifestation in the healthcare system. Ayurveda views constituents of human body in different perspective than the modern medicine and hence the concept of disease manifestation also gets varied. Few differences are listed as follows:

\subsection{Modern Biomedicine's Model of Humans}

Modern medicine is considered as era of evidence and experiments "hard" science (evidence), It is quantitative and structure based, it is reductionist study of components in isolation, it explains systems functioning in terms of physicochemical pathways, it is anthropocentric and it says that humans link with environment is at community level and environment's role concerned in community health and disease. It views psyche and soma as distinct and independent, health as a stable status of physicochemical norms, it is considered that health is an external declaration by the consultant that somebody is healthy and only physical health is considered as health ${ }^{1}$.

\subsection{Ayurveda's Model of Humans}

Ayurveda is science of pre evidence based/ Vedic era "hard-soft" science believe on evidence and perception intuition, it is qualitative and process based involves systems and multilevel networks. Its functioning is not limited to physicochemical pathways alone there exists multilevel interactions and supracorporal components, which contribute to physiology. It is considered as ecocentric which deals with giving importance to state of mind and also sees humans are individuals, intimately linked to environment and environment has direct role in individual health. Diseases are considered psychosomatic and interactive; it is believed that health is a multilevel process of psychosomatic harmony and health has also an internal experience of wellbeing by the subject and also there is an equally important psycho spiritual component in health ${ }^{1}$.

\subsection{Molecular Approach of Disease Manifestation}

Understanding the molecular machineries of a disease that can be rationalized to design effective drugs and improves human health care remains a fundamental goal of medical science. In medical terms, a disease is defined as a condition that demonstrates adverse effects on normal human physiology under the influence of various factors, which are mainly characterized as either genetic or environmental. Since a disease is characterized by its symptoms, the current principle of medical science seeks its cure in a symptom-guided manner ${ }^{2}$.

Most of the time diseases are phenotypic representation of proteins quality and quantity disorders, either at DNA, transcriptional, translational or post translational levels. Disease is a pathological condition of a part, organ, or system of an organism resulting from various causes, such as infection, genetic defect, or environmental stress, and characterized by an identifiable group of signs or symptoms.

\subsubsection{Different Groups of Molecular Defects}

It includes defects in extracellular structural proteins, defects in metabolic pathways (including enzymes, ion channels and transporters), defects in folding, processing and degradation of macromolecules, defects in hormones and signal transduction mechanisms, defects 
in nuclear proteins and transcriptional factors, defects in oncogenes and tumor-suppresser genes, defects in DNA, RNA processing and metabolism. These are the possible molecular defects which lead to enormous number of complications in the body and hence cause disease condition ${ }^{3}$.

Extracellular protein defect - Collagens are present in the ECM as fibrillar proteins and give structural support to resident cells. Collagen is exocytosed in precursor form (procollagen), which is then cleaved by procollagen proteases to allow extracellular assembly. Disorders such as osteogenesis imperfecta, and epidermolysis bullosa are linked with genetic defects in collagen-encoding genes ${ }^{4}$.

Structural proteins defects - In order to be functionally active, a protein has to acquire a unique $3 \mathrm{D}$ conformation via a complicated folding pathway, which is described by the primary amino acid sequence and the local cellular environment, error in the folding process results in a misfolded structure, which can sometimes be lethal. Under some conditions proteins fail to fold correctly, or to remain correctly folded, in living systems, and this failure can result in a wide range of diseases. One group of diseases, known as amyloidosis, which includes Alzheimer's and the transmissible spongiform encephalopathy, involves deposition of aggregated proteins in a variety of tissues. These diseases are particularly intriguing because evidence shows that the formation of the highly organized amyloid aggregates is a generic property of polypeptides, and not simply a feature of the few proteins associated with recognized pathological conditions ${ }^{5}$.

Genetic disorders - An inherited disorder is caused by defective genes that can be passed down by parents to their children. Defective genes can occur on any of the chromosomes. A genetic disorder can be autosomal dominant, autosomal recessive, or sex linked (Down's syndrome, Cancer) ${ }^{6}$.

Metabolic disorders - Inherited metabolic disorders are genetic conditions that result in metabolism problems. Most people with inherited metabolic disorders have a defective gene that results in an enzyme deficiency. A metabolic disorder occurs when abnormal chemical reactions in body disrupt this process. When this happens, person might have too much of some substances or too little of other ones that are needed to stay healthy (Diabetes) ${ }^{6}$.

Ion channels disorders - Ion channels serve many functions apart from electrical signal transduction: chemical signalling (Ca2p as a second messenger), transepithelial transport, regulation of cytoplasmic or vesicular ion concentration and $\mathrm{pH}$, and regulation of cell volume. Therefore, ion channel dysfunction can cause diseases in many tissues (Cystic Fibrosis, Arrythmias) ${ }^{7}$.

Trafficking disorders - It is a family of disorders that involve vesicular delivery of proteins. SNARE proteins assist with vesicle trafficking and are responsible for the fusion events between the membranes of vesicles and the membranes of their targets. (Familial hypercholesterolemia) ${ }^{8}$.

Signaling disorders - Our bodies are composed of billions of cells that work together. Each cell responds to external signals from other cells, and from its environment. Errors in signaling interactions and cellular information processing are responsible for diseases (Diabetes mellitus) ${ }^{9}$.

Molecular pathology is an evolving field that examines and identifies the molecules involved in specific diseases. The molecular pathologist utilizes techniques from molecular biology to study differences between normal and diseased tissue at the molecular level, so that the specific molecules associated with the disease may be identified.

\subsubsection{Relevance of Molecular Pathology}

Diagnosis: Looking at the disease from the small molecules point of view elucidates the causes of the disease (viruses, hereditary, disruptions of the normal control processes, such as the cell-cycle, apoptosis etc), provides a more comprehensive understanding of disease, it's natural history, and progression. It provides an understanding of the overall complexity of the disease.

Prognosis: It associates specific molecules or a set of molecules with the probable outcome of a disease.

With the entire human genome sequenced, it has become easier than it was decades ago to identify the genes that are causally linked to particular diseases. Unfortunately, identification of the gene responsible for a disease does not lead necessarily to a cure. To develop a therapy or cure, we need to understand where and when 
the particular gene is expressed, and more importantly, how the gene functions in normal as well as in affected cells.

\subsection{Ayurvedic Approach of Disease Manifestation}

Ayurveda teaches us the science of life from a micro to a macro level. Therefore, it conceptualized with concrete fundamental theories, and begins with the theory of evolution of the universe (Brahmanda) and the entire life forms (Pinda) prevailing in it $(\mathrm{Ch} . \mathrm{Sh} 5 / 3,4,5)^{10}$ (including human beings, plants, animals and microbes etc.), this is well supported with non living components like soil, water, minerals and metals. According to Ayurveda, all the living and non-living things are made up of the five elementary principles (Panchamahabhuta) which are derived from the three effective principles/energies of nature called Prakriti ${ }^{11}$.

Aakash + Vaayu $=$ VATA (Having features of both Aakash and Vaayu)

$\mathrm{Jal}+$ Agni $=$ PITTA (Having features of both Jal and Agni)

$J a l+$ Prithvi $=$ KAPHA (Having features of Jal and Prithvi)

Every individual is different from another and hence should be considered as a different entity. As many variations are there in the universe, all are seen in human beings.(Su.sh 4/98; Ch.Su1/124; Ch.Vi 4/12) ${ }^{12-}$ 14. This dictum of Ayurveda said by Acharya Charaka is fundamental to the concept of Prakriti. Etymologically Prakriti $($ pra $=$ primary or first, $K r i t i=$ formation or creation) stands for the prototype representing the basic formative distinction in a given individual i.e., natural predisposition. Proportions of Tridosha are determined genetically (Shukra Shonita) and are influenced by the environmental factors (maternal diet, lifestyle) during development. Ethnicity (Jatiprasakta), familial characteristics (Kulanupatini), and geoclimatic regions (Deshanupatini) are known to influence the phenotypic variability $^{15}$. Constitutional type of an individual or Prakriti is the basic clinical denominator in Ayurveda. It is described to be formed of characteristic physiological, physical and mental features of an individual, and is classified into subgroups depending on specific Dosha predominance. Seven subgroups of Prakriti are possible representing a differential combination or equi-presence of each one of the Tridosha, namely Vata, Pitta and Kapha. Knowledge of the basic Prakriti of a person is useful to stay in a state of positive health and prevent disease. The large number of phenotype description by Prakriti determination is based on the knowledge and experience of the assessor, and hence subject to inherent variations and interpretations ${ }^{15}$. Ayurveda describes the subject matter into three major categories termed 'Trisutra', meaning the three interconnected aspects of causes (hetu), features (linga) and therapeutics (aushadha) both for healthy and diseased people ${ }^{16}$.

\subsubsection{Role of Mansika Prakriti in Disease Manifestation}

Half of the people who seek medical advice primarily their mind is sick although they don't know it, they become victims of emotional disturbances which so affect function of their body that they become physically ill. According to Charaka the diseases both physical and mental have originated from anger and envy ( Ch.Ni1/15) (17) therefore if we want perfect health we cannot ignore the value of mental health. In Ayurveda diseases have been divided in to bodily and mental.(Ch.Su1/55) ${ }^{18}$, the bodily diseases are caused due to derangement of Tridosha (Vata, Pitta, Kapha). Similarly, mental diseases are caused by Rajas and Tamas which are Doshas of mind. These are the source of Kaam, Krodha, Moha, Shoka, Lobha, Mada, Matsarya, Eershya, Chittodvega, Bhaya leading to the mental diseases (Ch.Ni1/15) ${ }^{17}$. Doshas are physical and mental present in different proportion in different individuals forming the Deha and Manas Prakriti, which shows the psychosomatic expressions of individual. Satva, Raja and Tama are the Manasika Gunas, physical and mental constitution gets developed at the time of conception. Manasika Prakriti or psychic function of individual like Kama or Krodha etc. have been treated as cause of physical diseases. Similarly bodily Doshas too cause mental diseases e.g. Unmad has been classified according to bodily Doshas as Vatic, Paittic, Kaphaj and Tridoshaja Unmad (Ch.Ni7/3) ${ }^{19}$. This view has been further supported by Sharangadhar showing the relationship of Trigunas with Tridoshas, as Vata is associated with Rajas, Pitta with Sattvaguna and Kapha with Tamoguna.(Sh. Pu.5/44,47,52) ${ }^{20}$. 
Ayurveda is the holistic science it covers mind, body and soul for total health. Mental health is directly related with our physical health or vice versa. In molecular science factors which do not participate in alteration of genomic setup but create condition which can affect gene expression are dealt under the heading of epigenetics, for example, misuse of senses like stress, addiction, anxiety, depression can affect the body at molecular level, it has been stated that among all diseases around $95 \%$ of diseases are not inherited, which directly reflects that choices we make in our daily life directly affect the disease susceptibility and manifestation, so proper use of senses can overtake genetic factors and further can modify its expression ${ }^{21}$.

\subsubsection{Prakriti based Diagnosis and Classification of Related Diseases}

Disease begins when person is living out of harmony with his own environment. Inappropriate impression from environment disturbs the internal environment and cause disharmony. In Ayurveda, state of perfect health is balanced status of three doshas Vata, Pitta, Kapha.

Tridosha comprises three ascertainable physiological entities, namely, Vata (kinetic), Pitta (metabolic) and Kapha (potential) that are pervasive across systems, working conjunction with each other, and respond to external environmental conditions to maintain homeostasis (Ch.Su.1/57-61 ${ }^{22}$ and Ch.Su.18/47-5323; S.Su.21/3-4024; A.S.Su. $19 / 3^{25}$ and A.S.Su.20/3- $7^{26}$ ). Just like Sun, Moon, and Wind maintains the Universe same way their representative Vata, Pitta, Kapha maintains the body.(S.Su 21/8) ${ }^{27}$.

Distinct properties and functions have been ascribed to each dosha (Prasher et al. 2008). For instance, Vata (V) contributes to manifestation of shape, cell division, signaling, movement, cognition and excretion of wastes. It is also considered to be an initiator of the activities of Kapha (K) and Pitta (P) (Ch. Su. $12 / 3-13^{28}$ and Ch.Ci.28/3-2329). Pitta is primarily responsible for metabolism, thermoregulation, energy homeostasis, pigmentation, vision and host surveillance (Ch.Su.12/12 $2^{30}$ and Ch.Su.18/47-53 ${ }^{31}$ ). Kapha is responsible for anabolism, growth and maintenance of structure, storage and stability (Ch.Su.12/12-13 ${ }^{32}$ and Ch.Su.18/47-53 ${ }^{31}$ ). Each individual is born with a specific proportion of Tridosha $(\mathrm{V}, \mathrm{P}$ and $\mathrm{K})$ that determines his/her basic constitution, which is termed as their 'Prakriti' (Ch.Vi.8/95-10033; Su.Sh.4/6334). The proportions of Tridosha in the gametes of the parents at the time of fertilization contribute to the process of fetal development, and they shape and influence multisystemic phenotypic traits, including each person's receptiveness to extrinsic and intrinsic factors, thereby prompting their susceptibility to diseases (Ch.Vi.8/95$100^{33}$; Su.Sh.4/62-9935).

Based on the change in the homeostatic state of Tridosha different types of diseases and their severity can be decided. Charak described disease specific for Doshas, there are eighty disease for Vata, fourty for Pitta and twenty for Kapha (Ch.Su 20/ 11,14,17) ${ }^{36}$.

The Vata Prakriti individuals are prone to diseases of the neurological system especially motor functions. The diseases mostly affect the lower limbs since they are the predominant seat of Vata Dosha (Table 1). Also, Vata diseases are pronounced during the old age which is the period of Vata (Vata Kala). The Pitta Prakriti individuals are prone to diseases of the digestive and metabolic systems. The diseases mostly affect the abdomen area i.e. the area between the breast and umbilicus. Also, Pitta disorders are pronounced during the middle ages which is the period of Pitta (Pitta Kala). The Kapha Prakriti individuals are prone to diseases of the respiratory system especially phlegmatic disorders. The diseases mostly affect the upper parts of the body i.e. chest and above (Table 1). Also, the disorders are pronounced during the early ages (Childhood) which is the period of Kapha (Kapha Kala) (Ch.Vi.8/95-98) ${ }^{37}$.

\subsubsection{Disease Diagnosis for Treatments in Ayurveda}

The main task of the Ayurvedic physician is to diagnose the imbalance of one or several Doshas, and treatment includes re-establishing the proper balance. In Ayurveda, the diagnosis extends beyond the limit of an objective description of what is wrong with the patient. It envelops all anatomical structures; for instance, bodily constituents (Dhatu-s), excretory products (Mala-s), digestive power (Agni), and body channels (Srota-s), all of which can be involved in disease manifestation ${ }^{38}$.

The individuals with combinations of any two Doshas are susceptible to diseases of both types of the Doshas, (i.e. Vata-Pitta, Pitta-Kapha or Kapha-Vata types). It 
Table 1. Showing the list of few common probable disease manifestations as per Prakriti

\begin{tabular}{lll}
\multicolumn{1}{c}{ Vata } & \multicolumn{1}{c}{ Pitta } & Kapha \\
\hline - Tetany & - Intense localised burning & Drowsiness \\
- Wasting disorders (Muscular atrophy) & sensation & - Excessive sleep \\
- Spasms & Stomatitis & Obesity \\
- Hemiplegia & - Acid regurgitation & - Swelling of the neck (Galaganda) \\
- Convulsions & Jaundice & - Thick skin eruptions \\
- Headache & Bleeding disorders & Congestion of the chest with \\
- Insomnia & Bluish discoloration of the skin & phlegm \\
- Angina (Hridgraha) & Polyuria \\
- Dysuria & & \\
- Rheumatism (Amavata) & & \\
- Osteoporosis (Asthikshaya) & & \\
- Cracking of Sole and palm (Vippadika) & & \\
- Swelling and stiffness of the thighs & & \\
- (Urusthamba) & & \\
\hline
\end{tabular}

is mentioned in Ayurveda that these types are worst in terms of health due to combination of opposite qualities and thereby, selection of drugs to combat the same is a difficult task especially for individuals of Kapha-Pitta predominance. Due to the permutation and combination of Doshas $(\mathrm{V}, \mathrm{P}, \mathrm{K})$ sixty-two types of diseases are produced $\left(\right.$ Ch.Su 17/42-44) ${ }^{39}$.

Sama Prakriti individuals are the best in terms of health. They have constitution in which the three doshas are in perfect equilibrium. As such they do not have an inborn or natural 'susceptibility' to any type or group of diseases. They are considered as the ideal in terms of health. They possess a constitution in which the three Doshas are in perfect equilibrium. Sama Dosha Prakriti persons are found to be least affected with hereditary ailments (Ch.Su.7/40) ${ }^{40}$.

People belonging to specific Dosha Prakritis are more susceptible to diseases having the predominance of the same Doshas. For example, Vata-Kapha Prakriti individuals are found to be susceptible to Kasa (cough) which is Vata-Kapha predominant disease. People belonging to Dwandaja (dual) Prakriti were found to be more susceptible to ailments than those belonging single Prakriti.

\subsubsection{Role of Mansika Prakriti in Disease Diagnosis and Treatment}

Assessment of Manasika Prakriti is very much important for the maintenance of health as well as to prescribe therapeutics. It is designed according to predominance of any one or two Mansika Doshas Rajas and Tamas (Ch. Su1/57) ${ }^{41}$ therefore, the assessment of Manasika Prakriti of an individual is essential for prevention and treatment of diseases. 16 types of Manas Prakriti have been described in (Su.Sha 4/81-99) ${ }^{42}$ i.e. seven Sattvika type, six Rajasik type and three Tamsik type and their characteristic features have also been described considering which, an attempt should be made to adapt Sattvika properties which is free from diseases (Table 2). Sattvika type of Prakriti is best among all because of predominance of Sattva which is considered entirely pure, is not likely to vitiate or get vitiated. Thus, only Rajas and Tamas are considered as Manasika Doshas in Ayurveda. So Rajasika and Tamasika Prakriti persons are more prone to various diseases and are difficult to be cured in comparison to Sattvika Prakriti. In order to get rid of all the physical and mental diseases attempt should be made to avoid improper use of Indriyas with their objects (excessive use, disuse and no use) similarly the Pragyaparadha (delusion of mind) and violation of time factors have to be avoided. (Ch.Ni1/3) ${ }^{43}$ i.e., The Trigunatmaka Prakriti i.e., mental constitution of individuals can be diagnosed on the basis of their liking of food. (Bhagwat Gita Chapt $17 / 8,9,10)^{44}$ and accordingly can be modulated to get positive response. Here, it is also pertinent to mention that Mahat is the common source of Triguna, Tridosha and Panchmahabhutas. Similarly, Tridoshas are nothing but another name given to combination of Panchmahabhutas (As. Sam.Su.20/3) ${ }^{45}$. According to Charaka a treatment of 
Table 2. According to Ayurveda factors affecting prognosis of disease (Ch.Su.10/12-18) ${ }^{48}$

\begin{tabular}{|c|c|c|c|c|}
\hline \multirow[t]{2}{*}{ Factors/Criteria } & \multicolumn{2}{|c|}{ Curable } & \multicolumn{2}{|c|}{ Incurable } \\
\hline & Easily curable & Curable with difficulty & Palliable & Absolutely incurable \\
\hline Causative factors & Less & More & More & All \\
\hline $\begin{array}{l}\text { Premonitory } \\
\text { signs }\end{array}$ & Less & More & More & All \\
\hline $\begin{array}{l}\text { Severity of signs/ } \\
\text { symptoms }\end{array}$ & Mild & Moderate & Severe & $\begin{array}{l}\text { Severe and advanced } \\
\text { stages }\end{array}$ \\
\hline $\begin{array}{l}\text { Dosha involved } \\
\text { in disease }\end{array}$ & $\begin{array}{l}\text { Opposite to one's } \\
\text { Prakriti [constitution] }\end{array}$ & $\begin{array}{l}\text { Same as of Prakriti/ } \\
\text { favorable to disease }\end{array}$ & $\begin{array}{l}\text { Same as of Prakriti / } \\
\text { favorable to disease }\end{array}$ & $\begin{array}{l}\text { Same as of Prakriti / } \\
\text { favorable to disease }\end{array}$ \\
\hline $\begin{array}{l}\text { Dushya [body } \\
\text { tissues affected] }\end{array}$ & $\begin{array}{l}\text { Opposite to one's } \\
\text { Prakriti [constitution] }\end{array}$ & $\begin{array}{l}\text { Same as of Prakriti/ } \\
\text { favorable to disease }\end{array}$ & $\begin{array}{l}\text { Same as of Prakriti / } \\
\text { favorable to disease }\end{array}$ & $\begin{array}{l}\text { Many tissues, deep } \\
\text { seated and Favorable } \\
\text { to disease }\end{array}$ \\
\hline $\begin{array}{l}\text { Place of living of } \\
\text { patient }\end{array}$ & $\begin{array}{l}\text { Opposite to one's } \\
\text { Prakriti [constitution] }\end{array}$ & $\begin{array}{l}\text { Same as of Prakriti/ } \\
\text { favorable to disease }\end{array}$ & $\begin{array}{l}\text { Same as of Prakriti / } \\
\text { favorable to disease }\end{array}$ & $\begin{array}{l}\text { Same as of Prakriti / } \\
\text { favorable to disease }\end{array}$ \\
\hline $\begin{array}{l}\text { Season/time of } \\
\text { affection /Age }\end{array}$ & $\begin{array}{l}\text { Opposite to one's } \\
\text { Prakriti [constitution] }\end{array}$ & $\begin{array}{l}\text { Same as of Prakriti/ } \\
\text { favorable to disease }\end{array}$ & $\begin{array}{l}\text { Same as of Prakriti / } \\
\text { favorable to disease }\end{array}$ & $\begin{array}{l}\text { Same as of Prakriti / } \\
\text { favorable to disease }\end{array}$ \\
\hline $\begin{array}{l}\text { Movement of } \\
\text { Dosha }\end{array}$ & One sided & Two sided & $\begin{array}{l}\text { Many ways for } \\
\text { movements }\end{array}$ & $\begin{array}{l}\text { All ways for } \\
\text { movements/all } \\
\text { systems involved }\end{array}$ \\
\hline $\begin{array}{l}\text { Duration of } \\
\text { onset }\end{array}$ & New onset & Chronic, but still recent & $\begin{array}{l}\text { Very chronic and } \\
\text { continuously affecting } \\
\text { the patient }\end{array}$ & $\begin{array}{l}\text { Very chronic and } \\
\text { continuously affecting } \\
\text { the patient }\end{array}$ \\
\hline Complications & No & Minor/less complications & Many complications & $\begin{array}{l}\text { Many complications } \\
\text { with bad prognostic } \\
\text { signs }\end{array}$ \\
\hline $\begin{array}{l}\text { Number of } \\
\text { involved Dosha }\end{array}$ & One & Two & Two & Three \\
\hline Body & Can tolerate all medicines & $\begin{array}{l}\text { Occurred in pregnancy, } \\
\text { children, old age }\end{array}$ & $\begin{array}{l}\text { Affecting vital organs, } \\
\text { major joints }\end{array}$ & $\begin{array}{l}\text { Weak body, Affecting } \\
\text { vital organs, major } \\
\text { joints }\end{array}$ \\
\hline $\begin{array}{l}\text { Nature of } \\
\text { treatment }\end{array}$ & Medicines & Surgical/ Agni/Kshara & $\begin{array}{l}\text { Continuous treatment } \\
\text { needed }\end{array}$ & $\begin{array}{l}\text { Transcend all } \\
\text { therapeutic measures }\end{array}$ \\
\hline $\begin{array}{l}\text { Four pillars of } \\
\text { management / } \\
\text { patient's nature }\end{array}$ & $\begin{array}{l}\text { With all qualities of } \\
\text { physician, patient, nurse } \\
\text { and medicines available }\end{array}$ & Not with all qualities & $\begin{array}{l}\text { The patient lives, } \\
\text { get relief for some } \\
\text { time after following } \\
\text { wholesome regimen } \\
\text { and the disease gets } \\
\text { triggered after a little } \\
\text { exposure to causative } \\
\text { factors also }\end{array}$ & $\begin{array}{l}\text { All senses of patients } \\
\text { are affected, signs like } \\
\text { undue excitement, } \\
\text { restlessness, confused } \\
\text { state of mind with bad } \\
\text { prognostic signs }\end{array}$ \\
\hline
\end{tabular}

physical diseases can be done by use of Daivaviyapashray, Yuktiviyapashray, Satvavajay Chikitsa. For treatment of mental diseases Charaka has advised the use of Gyan (knowledge),Vigyan (means of knowledge), Dhairya (patience and consolation), Samadhi (the seization of modification of mind) (Ch.Su1/58) ${ }^{46}$.
Epigenetics deals with fundamentally the lots of things that affects gene expression in the phenotype during different stages of the lifecycle, from prenatal environment, postnatal and childhood environment, lifetime social experiences, diet we chose, nutrition, exposure to toxins, lifestyle selection, our behavior, and ability to deal with stress, and their impact on gene 
expression. So throughout life, our selection of good and bad directly affect our body; finally, the susceptibility to disease and its therapeutics. Ayurveda also says that proper use of indriyas is very important to remain in state of healthy being Prajnaparadha affects our health and longevity. The Asatmendriyartha Samyoga and Parinama have a direct impact on different epoch of our life. So we can say that just like Deha Prakriti can be related to our genetic set up so, our Manasa Prakriti can also be related to epigenetic factors which indirectly impact on expression of genes ${ }^{47}$.

\subsubsection{Terms of Ayurveda Resemble with Genetics}

The concept of genetics mentioned in Ayurveda is about the Beeja (Sperm/ovum), Beejabhaga (Chromosome) and Beejabhagaavayava (Genes). The Shukra (male sperm) and Shonita (female ovum) can be taken as the basic entity Beeja. Beejabhaga refers to the chromosomes ${ }^{49}$. Beejabhagavayava is the most fundamental entity which can be grossly compared to a gene $\mathrm{e}^{50}$. It is responsible for the expression of a particular trait in an individual. Prakriti (innate constitution) is mentioned as the genetically determined relative proportion of Doshas within the normal range ${ }^{51}$.

Prakriti determines an individual's susceptibility to various diseases. It helps in the diagnosis and prognosis of a disease and helps in the selection of suitable therapeutics. In modern medicine instead of a personalized approach they are having a symptomatic approach. Hence it is difficult to incorporate the concept of Predictive, Preventive and Personalized medicine in a symptomatic approach. It provokes the thinking that the Prakriti (phenotypic features) mentioned in Ayurveda can be correlated in molecular terms which leads to the hypothesis that the Prakriti (Phenotype) can be linked with the Genotype of a human being ${ }^{52}$.

\section{Ayurgenomics: Its Relevance and Application}

Ayurveda, has a unique way of classifying human population based on individual constitution or Prakriti. Ayurveda's tridosha theory identifies principles of motion (Vata), metabolism (Pitta), and structure (Kapha) as discrete phenotypic groupings. Patwardhan et al. (2005) hypothesized in a paper that there is a genetic link to prakriti and as proof of this concept showed a correlation between HLA alleles and prakriti type, establishing a foundation and preliminary experimental support for the concept of an association between HLA alleles and the Ayurvedic Tridosha theory of individual Prakriti types. This work is a promoter for a wider revolution in the scientific investigation of Ayurveda in India, referred to as "Ayurvedic biology" and "AyuGenomics" description of the features clearly suggests that the innate characters or Dosha Prakritis represent phenotypes. Classifying humans based on phenotypes offers a challenge to biomedical science which has currently the technology to look for underlying genetic variations among the phenotypic datasets" 54 .

On pharmacogenetic perspective of Ayurveda, Dahanukar and Thatte ${ }^{55}$ have noted the different response styles to medication of people with different Doshic constitutions or Prakriti. Each of the parameters responsible for disease manifestation can be modulated by a large number of genes. Thus an enormous number of possibilities of combination of variants from different genes and environment could contribute not only to differences in clinical manifestation of disease but also to the variability in age of onset, availability of the complete sequence of the human genome, it is now possible to entertain the thought that not too far in the future, each individual would have a personalized health regime based on his/her genetic make-up. Ayurgenomics is an integrative approach of Ayurveda and Genomics for discovery of predictive markers for preventive and personalized medicine ${ }^{56}$.

\section{System Approach and Ayurveda}

Change in attention from genes to cells, systems approach is not only developing cell biology, but is also providing impetus for clinical medicine to shift from a reductionistic to a holistic approach for efficient disease management. A distinctive feature of Ayurveda is its systems approach to health and disease. Through the theoretical framework of Vata, Pitta and Kapha, Ayurveda offers a new paradigm for understanding the human system as a networked functional entity where in system properties are integral components. A central feature of modern medicine is addressing disease at the molecular 
level. Ayurveda, on the other hand, understands and addresses disease at the level of organism using system properties. In this sense, Ayurveda is systems biology at a higher level, in comparison to the current cellular-centric approach ${ }^{57}$. A major challenge of systems biology is to differentiate meaningful and functional variations from the neutral ones, comprehend their cumulative effects

Table 3. Researches showing association between Prakriti types and various parameters of health and disease

\begin{tabular}{|c|c|c|c|}
\hline S.No. & Author(s) & Article title \& Reference & Findings \\
\hline 1. & $\begin{array}{l}\text { Venkatraghavan } \\
\text { S,et.al }\end{array}$ & $\begin{array}{l}\text { Constitutional study of cancer patients } \\
\text { - its prognosis and therapeutic scope. } \\
\text { Ancient Science of Life. 1987; 7(2):110-5. } \\
61\end{array}$ & $\begin{array}{l}\text { Pitta dominance is found in the Prakriti pattern of } \\
\text { cancer patients followed by Kapha dominance. }\end{array}$ \\
\hline 2 & $\begin{array}{l}\text { Tripathi JS, Singh } \\
\mathrm{RH}\end{array}$ & $\begin{array}{l}\text { Concept of Deha Prakriti vis-à-vis Human } \\
\text { Constitution in Ayurveda Ancient } \\
\text { Science of Life. 1994;13(3-4):314-25. }{ }^{62}\end{array}$ & $\begin{array}{l}\text { Deha Prakriti is a psychosomatic constitution of an } \\
\text { individual which genetically determines the pattern } \\
\text { of susceptibility of an individual to different diseases, } \\
\text { prognosis, course, and complications }\end{array}$ \\
\hline 3. & Joshi RR & $\begin{array}{l}\text { A biostatistical approach to Ayurveda: } \\
\text { Quantifying the tridosha The Journal } \\
\text { of Alternative and Complementary } \\
\text { Medicine. 2004; 10:879-89.63 }\end{array}$ & $\begin{array}{l}\text { Statistical validation on a large scale shows the } \\
\text { accuracy of this study estimates with confidence } \\
\text { level above } 90 \% \text {, suited for prognosis applications } \\
\text { and systematic drug response analysis of Ayurvedic } \\
\text { medicines }\end{array}$ \\
\hline 4. & $\begin{array}{l}\text { Patwardhan B, } \\
\text { Joshi K, } \\
\text { Chopra A }\end{array}$ & $\begin{array}{l}\text { Classification of Human population } \\
\text { based on HLA Gene Polymorphism } \\
\text { and the Concept of Prakriti in } \\
\text { Ayurveda. Journal of Alternative and } \\
\text { Complementary Medicine. 2005; } \\
\text { 11:349-53. }{ }^{64}\end{array}$ & $\begin{array}{l}\text { A significant correlation exists between HLA type } \\
\text { and Prakriti type indicating a genetic basis exist for } \\
\text { the three major constitutions (Vata, Pitta, Kapha) } \\
\text { described in Ayurveda. }\end{array}$ \\
\hline 5. & Hankey A & $\begin{array}{l}\text { A test of the systems analysis underlying } \\
\text { the scientific theory of Ayurveda's } \\
\text { Tridosha The Journal of Alternative } \\
\text { and Complementary Medicine. } \\
2005 ; 11(3): 385-90.65\end{array}$ & $\begin{array}{l}\text { The universality of coenzyme A implies that it is } \\
\text { evolutionary invariant with its identified role and } \\
\text { supports the system analysis identifying the Doshas }\end{array}$ \\
\hline 6. & Hankey A & $\begin{array}{l}\text { The scientific value of Ayurveda } \\
\text { The Journal of Alternative and } \\
\text { Complementary Medicine. } \\
2005 ; 11(2): 221-5.66\end{array}$ & $\begin{array}{l}\text { Prakriti of an individual depends on the inheritable } \\
\text { properties of encoded proteins and their identifiable } \\
\text { alleles in the genome thus making them interrelated. }\end{array}$ \\
\hline 7. & $\begin{array}{l}\text { Patwardhan B, } \\
\text { Bodecker G }\end{array}$ & $\begin{array}{l}\text { Ayurvedic genomics:Establishing a } \\
\text { genetic basis for mind-bod typologies } \\
\text { Journal of Alternative and } \\
\text { Complementary Medicine. } \\
2008 ; 14(5): 571-6 . .^{53}\end{array}$ & $\begin{array}{l}\text { The findings suggest a commonality exist between } \\
\text { Asia's medical traditions in their diagnostic typologies } \\
\text { and genetic basis for medicines theory of discrete and } \\
\text { discernable groups of psycho-physiologic differences }\end{array}$ \\
\hline 8. & PrasherB,et.al & $\begin{array}{l}\text { Whole Genome expression and } \\
\text { biochemical correlates of extreme } \\
\text { constitutional types defined in Ayurveda } \\
\text { Journal of Translational Medicine. 2008; } \\
6: 48.67\end{array}$ & $\begin{array}{l}\text { Individuals from the three constitutional types exhibit } \\
\text { striking differences with respect to biochemical, } \\
\text { hematological parameters, and at genome wide } \\
\text { expression levels which ultimately can help in } \\
\text { differential disease predisposition }\end{array}$ \\
\hline 9. & Aggarwal S.et.al & $\begin{array}{l}\text { EGLN1 involvement in high- altitude } \\
\text { adaptation revealed through genetic } \\
\text { analysis of extreme constitution types } \\
\text { defi ned in Ayurveda. Proceedings of } \\
\text { Natural Academy of Science USA. 2010; } \\
\text { 107(4):18961-6. }{ }^{68}\end{array}$ & $\begin{array}{l}\text { The study shows that EGLN1 polymorphisms } \\
\text { are associated with high-altitude adaptation } \\
\text { an expressions and genetic analysis of healthy } \\
\text { individuals phenotyped could uncover genetic } \\
\text { variations that are associated with adaptation to } \\
\text { external environment and susceptibility to diseases. }\end{array}$ \\
\hline
\end{tabular}


10. Hankey A

Joshi K, Ghodkey,

11. Shintre $P$

12. Rizzo-Sierra CV

13. Chatterjee B, Pancholi J

14. Purva MC,
Meena MS

15. Ghodke Y, Joshi K Patwardhan B

16. Mukherji M, Prasher B

Mahalle NP, Kulkarni

17. MV, Pendse NM, Naik SS

18. Nayak J

Tiwari S,

19. Gehlot S, Singh G
Establishing the scientific Validity of Tridosha Part 1:Doshas, Subdoshas and Dosha Prakritis Ancient science of Life. 2010; 29(3):6-18. ${ }^{69}$

Traditional medicine and genomics Journal of Ayurveda and Integrative Medicine. 2010; 1(1):26-32. ${ }^{70}$

Ayurvedic genomics, constitutional psychology and endocrinology: The missing connection Journal of Alternative and Complementary Medicine. 2011; 17(5):465-8. ${ }^{71}$

Prakriti-based medicine: A step towards personalized Medicine AYU. 2011; 32(2):141-6. ${ }^{72}$

A review on role of Prakriti in aging AYU. 2011; 32(1):20-4. ${ }^{73}$

Traditional medicine to modern pharmacogenomics: Ayurveda Prakriti type and CYP2C19 gene polymorphism associated with metabolic variability. Evidence Based Complementary and Alternative Medicine. 2011: 2011:249528. ${ }^{74}$

Ayurgenomics: A new approach in Personalized and Preventive Medicine Science and Culture, Jan-Feb 2011; 77(1-2):10-17.52

Association of constitutional type of Ayurveda with cardiovascular risk factors, inflammatory markers and insulin resistance. Journal of Ayurveda and Integrated Medicine. 2012; 3(3). ${ }^{75}$

Ayurvedaresearch: Ontological challenges Journal of Ayurveda and Integrated Medicine. 2012; 3(1):17-20. ${ }^{1}$

Effect of walking (aerobic isotonic exercise) on physiological variants with special reference to Prameha (diabetes mellitus) as per Prakriti. AYU. 2012; 33(1):44-9. ${ }^{76}$
Tridosha is applied to every living organism and shows how individual differences in Prakriti originate in fundamental systems functions shared by all forms of life and are implemented by genes responsible for Relevant cellular functions (Vata-homeostasis, Pitta-turnover, Kapha-storage)

The paper revealed that human Prakritican be empirically validated at the genomics level and layout scientifically validated approaches to preventive medicines, chronic diseases, and treatments.

Three basic extreme genopsycho - somatotypes or birth constitutions (Pitta, Kapha, Vata) have different nuclear receptors which are expected to regulate the expression of specific genes, thereby controlling embryonic development, adult homeostasis, and metabolism of the human organism in a very profound way

The Golden Triangle of Ayurveda, modern science, and modern medicine can pave the path to personalized medicine and offer remedies to challenging health issues

Aging and Prakriti are closely related to each other. Prakriti individual types tend to suffer early with decaying process and other changes of aging when supported by Vata Prakriti

A significant correlation was found between CYP2C19 genotypes and Prakriti indicating that Kapha and Pitta Prakriti being low and fast metabolizer groups are likely to require low and high doses of CYP2C19 substrates

This study has provided a novel molecular framework for integration of predictive and personalized medicine and highlighted that Ayurgenomics approach can accelerate/assist predictive marker discovery.

There is strong relation of risk factors (diabetes, hypertension, and dyslipidemia), insulin resistance and inflammatory markers with Vata Kapha and Kapha Prakriti

For a collaborative research to occur at required levels, a mutually acceptable vocabulary should be developed between Ayurveda, modern biomedical, as well as other sciences belonging to different ontology

Strong association is seen between Prakriti, blood pressure, and biochemical parameters. Maximum number of cases belonged to Vata-Pitta Prakriti and minimum number of cases belonged to Vata-Kapha Prakriti 
Juyal RC, Negi S,

Wakhode $\mathrm{P}$,

20.

Bhat S, Bhat B, Thelma BK

Bhalerao S,

21. Deshpande T, Thatte U

22. Manyam BV, Kumar A.

23. Rotti.H.,et.al

24. Subhojit Dey and Parika Pahwa..

25. Rotti H,et.al

26. Pooja D. Gupta

Shirolkar SG,

27. Tripathi RK, Rege NN.

28. Rotti H.et.al

Prasher B.,

29. Gibson G. and Mukerji M.
Potential of ayurgenomics approach in complex trait research: Leads from a pilot study on rheumatoid arthritis PLOS One. 2012; 7(9):e45752. ${ }^{77}$

Prakriti (Ayurvedic concept of constitution) and variations in Platelet aggregation BMC Complementary and Alternative Medicine. 2012; 12:248. ${ }^{78}$

Ayurvedic constitution (prakruti) identifies risk factor of developing Parkinson's disease. J Altern Complement Med. 2013; (7):644-9. ${ }^{79}$

Immunophenotyping of normal individuals classified on the basis of human Dosha Prakriti. J Ayurveda Integr Med. 2014 Jan; 5(1):43-9. ${ }^{80}$

Prakriti and its associations with metabolism, chronic diseases, and genotypes Possibilities of new born screening and a lifetime of personalized prevention. J Ayurveda Integr Med. 2014 Jan-Mar; 5(1): 15-24. ${ }^{81}$

Determinants of Prakriti, the human constitution types of Indian traditional medicine and its correlation with contemporary science. J Ayurveda Integr Med. 2014 Jul; 5(3):167-75. ${ }^{80}$

Pharmacogenetics, Pharmaco-genomics and Ayurgenomics for Personalized Medicine: A Paradigm Shift. Indian J Pharm Sci. 2015 Mar-Apr; 77(2): $135-41 .^{82}$

Evaluation of prakriti and quality-oflife in patients with irritable bowel syndrome. Anc Sci Life. 2015 Apr-Jun;34(4):210-5. ${ }^{83}$

DNA methylation analysis of phenotype specific stratified Indian population. J Transl Med. 2015 May 8;13:151. ${ }^{84}$

Genomic insights into ayurvedic and western approaches to personalized Medicine. J Genet. 2016 Mar; 95 (1):209-28. ${ }^{2}$
Tridosha is applied to every living organism and shows how individual differences in Prakriti originate in fundamental systems functions shared by all forms of life and are implemented by genes responsible forrelevant cellular functions (Vata-homeostasis, Pittaturnover, Kapha-storage)

Maximum platelet aggregation was highest among Vata-Pitta Prakriti individuals and better responded to low dose of aspirin as compared to other Prakriti types so indicating Prakriti related variations in platelet aggregation response in healthy individuals

The study observes a correlation between having Vata Prakriti and an increased risk for developing Parkinson disease.

The increased level of CD25 and CD56 in Kapha Prakriti may indicate ability to elicit better immune response.

Personalized preventive health will result in healthy and more productive lives for children, which has also the potential to reduce the burden of disease as well as increasing costs faced by health systems due to rising incidence of chronic diseases.

The study demonstrated analysis of Prakriti classification and its association with $\mathrm{BMI}$ and place of birth with the implications to one of the ways for human classification

The principle of Ayurgenomics seems to bear similarities with that of pharmacogenetics/ pharmacogenomics and exhibits the potential to serve as a platform in achieving the concept of personalized drug therapy. The basis of individual variations in Ayurveda indicates that the individuals of different Prakriti may have different rates of drug metabolism associated with drug metabolizing enzyme (DME) polymorphism as well.

The study demonstrated majority of the Vata predominant patients had developed IBSConstipation; Pitta predominant patients had developed IBS-Diarrhoea. Quality of Life (QOL) was better in Pitta predominant individuals of all IBS-disease subtypes.

Differential DNA methylation signatures in three distinct Prakriti phenotypes demonstrate the epigenetic basis of Indian traditional human classification which may have relevance to personalized medicine

The identification of genes and pathways involved in development and manifestation of variable states of health, disease and responsiveness to drugs within and across populations will be crucial to integration 


\begin{tabular}{|c|c|c|c|}
\hline & & & $\begin{array}{l}\text { of personalized approaches in drug discovery and } \\
\text { development. This would also simultaneously } \\
\text { facilitate development of biomarker-based drug } \\
\text { delivery in a personalized manner. Trisutra, thus is an } \\
\text { operational framework for translational aspects of } \\
\text { network medicine with systems understanding. It can } \\
\text { also provide a theoretical framework for integrating } \\
\text { basic understanding at the systems level with } \\
\text { outcomes in health and disease and development of } \\
\text { personalized prevention and therapeutics. }\end{array}$ \\
\hline 30. & Prasher, B.et.al & $\begin{array}{l}\text { Ayurgenomics for stratified medicine: } \\
\text { TRISUTRA consortium initiative across } \\
\text { ethnically and geographically diverse } \\
\text { Indian populations. J Ethnopharmacol. } \\
2017 \text { Feb 2; 197:274-93. }{ }^{85}\end{array}$ & $\begin{array}{l}\text { Considering the molecular and genomics } \\
\text { differences underlying Prakriti and relevance in } \\
\text { disease pharmacogenomics studies, this novel } \\
\text { integrative platform would help in identification } \\
\text { of differently susceptible and drug responsive } \\
\text { population. Additionally, integrated analysis of } \\
\text { phenomic and genomic variations would not only } \\
\text { allow identification of clinical and genomic markers } \\
\text { of Prakriti for application in personalized medicine } \\
\text { but also its integration in drug discovery and } \\
\text { development programs. }\end{array}$ \\
\hline 31. & $\begin{array}{l}\text { Chauhan,N.S. } \\
\text { et.al }\end{array}$ & $\begin{array}{l}\text { Western Indian Rural Gut Microbial } \\
\text { Diversity in Extreme Prakriti Endo- } \\
\text { Phenotypes Reveals Signature Microbes } \\
\text { Front Microbiol. } 2018 \text { Feb 13; 9:118. }{ }^{86}\end{array}$ & $\begin{array}{l}\text { Study reveals that despite overall uniform } \\
\text { composition of gut microbial community, healthy } \\
\text { individuals belonging to different Prakriti groups } \\
\text { have enrichment of specific bacteria. It highlights the } \\
\text { importance of Prakriti based endo-phenotypes to } \\
\text { explain the variability amongst healthy individuals in } \\
\text { gut microbial flora that have important consequences } \\
\text { for an individual's health, disease and treatment. }\end{array}$ \\
\hline
\end{tabular}

at the system wide level, thereby linking them to phenotypes $^{58-60}$ (Table 3).

\section{Conclusion}

Although the Ayurvedic and modern biomedicine system are healthcare systems of different believes having different types of diagnostic and treatment patterns but disease management serves as a common point of interest for both conventional medicine and Ayurveda. Ayurveda and other traditional health-care systems across the world have suffered because very few studies have actually been attempted to understand the traditional ageold descriptions in contemporary vocabulary. But in order to find out the common ground in between both the field of Ayurgenomics attempts have been made to view how the molecular basis of disease can be correlated with the ancient healing system of Ayurveda. Ayurgenomics interprets the principles of Ayurveda with the latest modern tools and thereby it covers the way for evidence-based Ayurveda and thus attained better global acceptance. Personalised medicine remains an important concept of research and needs further perfection to make it more feasible for clinical practice. It can also provide a theoretical framework for integrating basic understanding at the systems level with outcomes in health and disease management and development of personalized prevention and therapeutics.

\section{Acknowledgements}

We would like to acknowledge Dr. Vandana Verma, Dr. Kishore Patwardhan for their valuable suggestion to improve the manuscript and also I would like to thank Dr. Rajesh Singh for his critical comments.

\section{References}

1. Nayak J. Ayurveda research: Ontological challenges. Journal of Ayurveda and Integrated Medicine 2012; 3(1):17-20. 
https://doi.org/10.4103/0975-9476.93942. PMid:22529675 PMCid:PMC3326789

2. Prasher B, Gibson G, Mukerji M. Genomic insights into ayurvedic and western approaches to personalized medicine. Journal of Genetics. 2016; 95(1):209-28. https://doi. org/10.1007/s12041-015-0607-9. PMid:27019453

3. Superdi-Furga A, Bonafé L, Rimoin DL. Molecular pathogenic classification of genetic disorder of skeleton. American Journal of Medical Genetics. 2001; 106:282-93. https://doi. org/10.1002/ajmg.10233. PMid:11891680

4. Plopper G. The extracellular matrix and cell adhesion. Cells. 2007.

5. Dobson CM. The structural basis of protein folding and its links with human disease. Philosophical transactions of the Royal Society of London Series B, Biological sciences. 2001; 356(1406):133-45. https://doi.org/10.1098/rstb.2000.0758. PMid:11260793 PMCid:PMC1088418

6. [Internet]. Available from: https://medlineplus.gov.

7. Dworakowska B. Ion channels-related diseases. Acta Biochimica Polonica. 2000; 47(3):685-703.

8. Olkkonen VM, Ikonen E. When intracellular logistics fails - genetic defects in membrane trafficking. Journal of Cell Science. 2006; 119:5031-45. https://doi.org/10.1242/ jcs.03303. PMid:17158910

9. [Internet]. Available from:http://www.auburn.edu/academic/ classes/biol/6190/CellSignalingBiology/csb012.pdf).

10. Charak. Charak Samhita. Chaukhambha sanskrit sansthan, Varanasi. 1979; 1(7):886.

11. [Internet]. Available from: https://www.bgci.org/education/1686.

12. Sushruta. Sushruta Samhita text. NS Prakashan, Bombay; 1945. p. 376.

13. Charak. Charak Samhita. Chaukhambha sanskrit sansthan, Varanasi. 1979; 1(7).

14. Charak. Charak Samhita. Chakhabha sanskrit sansthan. 1979; 7:786.

15. Sathya N. Dornala et al. Scientific validation of Ayurvedic concept of Prakriti (Psychosomatic Constitution). An International Journal of Research in AYUSH and Allied Systems. 2015; 2(5):297-303.

16. Sharma P. Charaka Samhita: Text with English translation. Chaukambha Orientalia Publisher, Varanasi, India; 1981. p. 240.

17. Charak. Charak Samhita. Chakhabha sanskrit sansthan, Varanasi, India. 1979; 1(7):609.

18. Charak. Charak Samhita. Chaukhambha sanskrit sansthan, Varanasi. 1979; 1(7):31.

19. Charak. Charak Samhita. Chakhabha sanskrit sansthan, Varanasi, India. 1979; 1(7):656.

20. Sharangdhar. Sharangdhar Samhita purva khand. Chakhabha surbharti, Varanasi, India. 1990:60-1.
21. Srinivasan TM. Genetic, epigenetics and pregenetics. International Journal of Yoga. 2011; 4(2):47-8. https://doi. org/10.4103/0973-6131.85484. PMid:22022121 PMCid: PMC3193653

22. Charak. Charak Samhita. Chaukamba sanskrit sansthan, Varanasi, India. 1979; 1(7):32-7.

23. Charak. Charak Samhita. Chakhabha sanskrit sansthan, Varanasi, India. 1979; 1(7):384-85.

24. Sushrute. Sushrute Samhita. NS Prakashan, Bombay. 1945:76-82.

25. Vagbhatta. Ashtanga Sangraha Vaidyanatha Bhawan, Nagpur. 1986:588.

26. Vagbhatta. Ashtang Sangraha. Vaidyanatha Bhawan, Nagpur. 1986:610-17.

27. Sushrute. Sushrute Samhita. NS Prakashan, Bombay. 1945:76.

28. Charak. Charak Samhita. chakhabha sanskrit sansthan, Varanasi, India. 1979; 1(7):243-52.

29. Charak. Charak Samhita. Chaukhabha Vidya Bhawan, Varanasi, India. 1962; 2:775-80.

30. Charak. Charak Samhita. Chakhabha sanskrit sansthan, Varanasi, India. 1979; 1(7):252.

31. Charak. Charak Samhita. Chakhabha sanskrit sansthan, Varanasi, India. 1979; 1(7):383-85.

32. Charak. Charak Samhita. Chakhabha sanskrit sansthan, Varanasi, India. 1979; 1:252.

33. Charak. Charak Samhita. Chakhabha sanskrit sansthan, Varanasi, India. 1979; 1(7):772-74.

34. Sushruta. Sushruta Samhita. NS Prakashan, Bombay; 1945. p. 371.

35. Sushruta. Sushruta Samhita. NS Prakashan, Bombay. 1945. p. 371-6.

36. Charak. Charak Samhita. Chakhambha sanskrit sansthan, Varanasi. 1979; 1(7):400-5.

37. Charak. Charak Samhita.Chakhabha sanskrit sansthan, Varanasi, India. 1979; 1(7):771-4.

38. Acharya YT. Caraka Samhita. Chaukhamba Surbharati, Varanasi. 1992.

39. Charak. Charak Samhita. Chakhabha sanskrit sansthan, Varanasi, India. 1979; 1:340-1.

40. Charak. Charak Samhita. Chakhabha sanskrit sansthan, Varanasi, India. 1979; 1(7):165.

41. Charak. Charak Samhita. Chakhabha sanskrit sansthan, Varanasi, India. 1979; 1(7):32.

42. Sushruta. Sushruta Samhita. NS Prakashan, Bombay. 1945:374-76.

43. Charak. Charak Samhita. Chakhabha sanskrit sansthan, Varanasi, India. 1979; 1(7):569.

44. Bhagwat Gita. Gita Press, Gorakhpur; 1954. p. 283-4.

45. Vagbhatt V. Ashtang Sangrah Sutra. Baidyanath Ayurveda Bhawan Pvt. 1986; (3):610.

46. Charak. Charak Samhita. Chakhabha sanskrit sansthan, Varanasi, India. 1979; 1(7):35. 
47. Sharma H. Ayurveda: Science of life, genetics, and epigenetics. Ayu. 2016; 37(2):87-91. https://doi.org/10.4103/ ayu.AYU_220_16. PMid:29200745 PMCid:PMC5688840

48. Charak. Charak Samhita. Chakhabha sanskrit sansthan, Varanasi, India. 1979; 1(7):204-6.

49. AcharyaYT. Charaka Samhita by Agnivesha. 4th ed. Chowkhambha Sanskrit Sansthan; 1997. p. 315.

50. Acharya YT. Charaka Samhita by Agnivesha. 4th ed. Chowkhambha Sanskrit Sansthan, $4^{\text {th }}$ edition; 1997. p. 322.

51. Acharya YT. Charaka Samhita by Agnivesha. Chowkhambha Sanskrit Sansthan, $4^{\text {th }}$ edition.; 1997. p. 277.

52. Chandran H, Arunraj GR, Ajayan. Ayurgenomics: A new research outlook. An International Journal of Advances in Pharmaceutical Sciences. 2014; 5(4):2214-6.

53. Patwardhan B, Bodeker G. Ayurvedic genomics: Establishing a genetic basis for mind-body typologies. Journal of Alternative and Complementary Medicine (New York, NY). 2008; 14(5):571-6. https://doi.org/10.1089/acm.2007.0515. PMid:18564959

54. Valiathan MS. Ayurvedic biology: A decadal vision document. Indian Academy of Sciences. 2006.

55. Dahanukar SA, Thatte UM. Current status of ayurveda in phytomedicine. Phytomedicine: International Journal of Phytotherapy and Phytopharmacology. 1997; 4(4):359-68. https://doi.org/10.1016/S0944-7113(97)80048-7

56. Mukherji BPM. Ayurgenomics: A new approach in personalized and preventive medicine. Science and Culture. 2011; 77(1-2):10-7.

57. Jayasundar R. If systems approach is the way forward, what can the Ayurvedic theory of Tridosha teach us? Current Science. 2017; 112(6). https://doi.org/10.18520/cs/v112/ i06/1127-1133

58. Gibson G. Visscher P. From personalized to public healthgenomics. Genome Med. 2013; 5(1-2). https://doi.org/10.1186/ gm464. PMid:23876409 PMCid:PMC3967116

59. Olson MV. What does a "normal" human genome look like? Science and Culture. 2011; 331(872). https://doi.org/10.1126/ science.1203236. PMid:21330527

60. Olson MV. Human genetic individuality. Annual Reviews: Human Genetic Individuality. 2012; 13:1-27. https://doi.org/10.1146/annurev-genom-090711-163825. PMid:22657391

61. Venkataraghavan S, Sunderesan TP, Rajagopalan V, Srinivasn K. Constitutional study of cancer patients - its prognostic and therapeutic scope. Ancient Science of Life. 1987; 7(2):110-5.

62. Tripathi JS, Singh RH. Concept of deha Prakriti vis-À-vis human constitution in Ayurveda. Ancient Science of Life. 1994; XIII Nos. (3 \& 4):314-25.

63. Joshi RR. A biostatistical approach to ayurveda: Quantifying the tridosha. Journal of Alternative and Complementary Medicine (New York, NY). 2004; 10(5):879-89. https://doi. org/10.1089/acm.2004.10.879. PMid:15650478
64. Bhushan P, Kalpana J, Arvind C. Classification of human population based on HLA gene polymorphism and the concept of Prakriti in Ayurveda. Journal of Alternative and Complementary Medicine (New York, NY). 2005; 11(2):34953. https://doi.org/10.1089/acm.2005.11.349. PMid:15865503

65. Hankey A. A test of the systems analysis underlying the scientific theory of Ayurveda's Tridosha. Journal of alternative and complementary medicine (New York, NY). 2005; 11(3):385-90. https://doi.org/10.1089/acm.2005.11.385. PMid:15992219

66. Hankey A. The scientific value of Ayurveda. Journal of Alternative and Complementary Medicine (New York, NY). 2005; 11(2):221-5. https://doi.org/10.1089/acm.2005.11.221. PMid:15865485

67 Prasher B, Negi S, Aggarwal S, Mandal AK, Sethi TP, Deshmukh SR, et al. Whole genome expression and biochemical correlates of extreme constitutional types defined in Ayurveda. Journal of Translational Medicine. 2008; 6:48. https://doi.org/10.1186/1479-5876-6-48. PMid:18782426 PMCid:PMC2562368

68. Aggarwal S, Negi S, Jha P, Singh PK, Stobdan T, Pasha MA, et al. EGLN1 involvement in high-altitude adaptation revealed through genetic analysis of extreme constitution types defined in Ayurveda. Proceedings of the National Academy of Sciences of the United States of America. 2010; 107(44):18961-6. https://doi.org/10.1073/pnas.1006108107. PMid:20956315 PMCid:PMC2973881

69. HankeyA. Establishing the scientific Validity of Tridosha Part 1:Doshas, Subdoshas and Dosha Prakritis Ancient science of life. 2010;29 (3):6-18.

70. Joshi K, Ghodke Y, Shintre P. Traditional medicine and genomics. Journal of Ayurveda and Integrative Medicine. 2010; 1(1):26-32. https://doi.org/10.4103/0975-9476.59824. PMid:21829298 PMCid:PMC3149388

71. Rizzo-Sierra CV. Ayurvedic genomics, constitutional psychology, and endocrinology: The missing connection. Journal of Alternative and Complementary Medicine (New York, NY). 2011; 17(5):465-8. https://doi.org/10.1089/acm.2010.0412. PMid:21563964

72. Chatterjee B, Pancholi J. Prakriti-based medicine: A step towards personalized medicine. Ayu. 2011; 32(2):141-6. https://doi.org/10.4103/0974-8520.92539. PMid:22408293 PMCid:PMC3296331

73. Purva MC, MS M. A review on role of Prakriti in aging. Ayu. 2011; 32(1):20-4. https://doi.org/10.4103/0974-8520.85719. PMid:22131753 PMCid:PMC3215411

74. Ghodke Y, Joshi K, Patwardhan B. Traditional medicine to modern pharmacogenomics: Ayurveda Prakriti Type and CYP2C19 gene polymorphism associated with the metabolic variability. Evidence-based complementary and alternative medicine: eCAM.2011;2011:249528. https://doi.org/10.1093/ ecam/nep206. PMid:20015960 PMCid:PMC3135904 
75. Mahalle NP, Kulkarni MV, Pendse NM, Naik SS. Association of constitutional type of Ayurveda with cardiovascular risk factors, inflammatory markers and insulin resistance. Journal of Ayurveda and Integrative Medicine. 2012; 3(3):150-7. https://doi.org/10.4103/0975-9476.100186. PMid:23125512. PMCid:PMC3487241

76. Tiwari S, Gehlot S, Tiwari SK, Singh G. Effect of walking (aerobic isotonic exercise) on physiological variants with special reference to Prameha (diabetes mellitus) as per Prakriti. Ayu. 2012; 33(1):44-9. https://doi.org/10.4103/0974-8520.100308. PMid:23049183. PMCid:PMC3456862

77. Juyal RC, Negi S, Wakhode P, Bhat S, Bhat B, Thelma BK. Potential of ayurgenomics approach in complex trait research: leads from a pilot study on rheumatoid arthritis. PloS one. 2012; 7(9):e45752. https://doi.org/10.1371/journal. pone.0045752. PMid:23049851. PMCid:PMC3458907

78. Bhalerao S, Deshpande T, Thatte U. Prakriti (Ayurvedic concept of constitution) and variations in Platelet aggregation. BMC Complementary and Alternative Medicine. 2012; 12(248). https://doi.org/10.1186/1472-6882-12-248. PMid:23228069. PMCid:PMC3562518

79. Manyam BV, Kumar A. Ayurvedic constitution (prakruti) identifies risk factor of developing Parkinson's disease. Journal of Alternative and Complementary Medicine (New York, NY). 2013; 19(7):644-9. https://doi.org/10.1089/ acm.2011.0809. PMid:23819563

80. Rotti H, Guruprasad KP, Nayak J, Kabekkodu SP, Kukreja $\mathrm{H}$, Mallya $\mathrm{S}$, et al. Immunophenotyping of normal individuals classified on the basis of human dosha prakriti. Journal of Ayurveda and integrative Medicine. 2014; 5(1):43-9. https://doi.org/10.4103/0975-9476.128857. PMid:24812475. PMCid:PMC4012362
81. Dey S, Pahwa P. Prakriti and its associations with metabolism, chronic diseases, and genotypes: Possibilities of new born screening and a lifetime of personalized prevention. Journal of Ayurveda and Integrative Medicine. 2014; 5(1):15-24. https://doi.org/10.4103/0975-9476.128848. PMid:24812471. PMCid:PMC4012357

82. Gupta PD. Pharmacogenetics, pharmacogenomics and ayurgenomics for personalized medicine: A paradigm shift. Indian Journal of Pharmaceutical Sciences. 2015; 77(2):135-41. https://doi.org/10.4103/0250-474X.156543. PMid:26009644. PMCid:PMC4442460

83. Shirolkar SG, Tripathi RK, Rege NN. Evaluation of prakrti and quality-of-life in patients with irritable bowel syndrome. Ancient Science of Life. 2015; 34(4):210-5. https://doi.org/10.4103/02577941.160865. PMid:26283806. PMCid:PMC4535069

84. Rotti H, Mallya S, Kabekkodu SP, Chakrabarty S, Bhale S, Bharadwaj R, et al. DNA methylation analysis of phenotype specific stratified Indian population. Journal of Translational Medicine. 2015; 13:151. https://doi.org/10.1186/s12967-0150506-0. PMid:25952924. PMCid:PMC4438459

85. Prasher B, Varma B, Kumar A, Khuntia BK, Pandey R, Narang A, et al. Ayurgenomics for stratified medicine: TRISUTRA consortium initiative across ethnically and geographically diverse Indian populations. Journal of Ethnopharmacology. 2017; 197:274-96. https://doi.org/10.1016/j.jep.2016.07.063. PMid:27457695

86. Chauhan NS, Pandey R, Mondal AK, Gupta S, Verma MK, Jain S, et al. Western Indian Rural Gut Microbial Diversity in Extreme Prakriti Endo-Phenotypes Reveals Signature Microbes. Frontiers in Microbiology. 2018; 9:118. https:// doi.org/10.3389/fmicb.2018.00118. PMid:29487572. PMCid: PMC5816807 